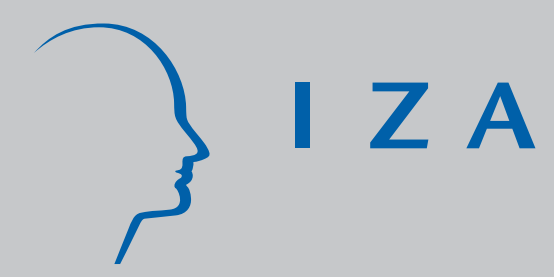

IZA DP No. 3052

Comparative Advantage or Discrimination? Studying Male-Female Wage Differentials Using Displaced Workers

Astrid Kunze

Kenneth R. Troske

September 2007 


\title{
Comparative Advantage or Discrimination? Studying Male-Female Wage Differentials Using Displaced Workers
}

\author{
Astrid Kunze \\ Norwegian School of Economics and Business Administration \\ and IZA \\ Kenneth R. Troske \\ University of Kentucky \\ and IZA \\ Discussion Paper No. 3052 \\ September 2007 \\ IZA \\ P.O. Box 7240 \\ 53072 Bonn \\ Germany \\ Phone: +49-228-3894-0 \\ Fax: +49-228-3894-180 \\ E-mail: iza@iza.org
}

Any opinions expressed here are those of the author(s) and not those of the institute. Research disseminated by IZA may include views on policy, but the institute itself takes no institutional policy positions.

The Institute for the Study of Labor (IZA) in Bonn is a local and virtual international research center and a place of communication between science, politics and business. IZA is an independent nonprofit company supported by Deutsche Post World Net. The center is associated with the University of Bonn and offers a stimulating research environment through its research networks, research support, and visitors and doctoral programs. IZA engages in (i) original and internationally competitive research in all fields of labor economics, (ii) development of policy concepts, and (iii) dissemination of research results and concepts to the interested public.

IZA Discussion Papers often represent preliminary work and are circulated to encourage discussion. Citation of such a paper should account for its provisional character. A revised version may be available directly from the author. 


\section{ABSTRACT \\ Comparative Advantage or Discrimination? Studying Male-Female Wage Differentials Using Displaced Workers*}

In this paper we empirically examine differences in search behavior between men and women. We assess hypotheses regarding duration of search, wages and tenure. The hypotheses are derived from two models: the equilibrium search model with discriminatory firms by Black (1995) and an opportunity cost model that extends the Black model by incorporating age varying reservation wages. We identify effects using data on displaced workers and a differences in differences approach. We find that for men and women the duration of search is equal once we limit our estimation to women with a constant number of children in the household. Furthermore, we find no significant differences in the quality of job match between men and women. Finally, male/female wage differentials are largest among young workers but a significant portion of the difference is accounting for by changes in the number of children in the household. All these results suggest that differences in search behavior and outcomes between men and women are due to differences in nonmarket opportunities rather than to discrimination.

JEL Classification: J0, J7

Keywords: $\quad$ search, displaced workers, discrimination, comparative advantage

Corresponding author:

Astrid Kunze

Department of Economics

Norwegian School of Economics and Business Administration (NHH)

Helleveien 30

5035 Bergen

Norway

Email: astrid.kunze@nhh.no

\footnotetext{
* We would like to thank Christopher Bollinger, John Garen, David Jaeger, Peter Mueser and seminar participants at the IZA summer workshop and the University of Miami for helpful comments. This research was begun while Troske was a visiting research fellow at IZA and he thanks them for financial support.
} 


\section{Introduction}

Much of the research examining differences in wages between men and women and the possible existence of labor market discrimination has focused on Gary Becker's (1971) canonical model of discrimination. In this model distaste on the part of employers for hiring minority workers results in the segregation of these workers into firms run by employers with less or no distaste for hiring minority workers. Wage differentials between men and women will only exist if the marginal employer dislikes hiring women. Thus, as long as there are enough nondiscriminatory employers in the market to employ all women, there will be no wage differential between men and women even if there are employers in the market who have distaste for hiring women. In addition, under certain conditions, the Becker model implies that competition should force discriminatory employers out of the labor market. This in turn implies that either the necessary conditions do not hold and that discrimination exists in labor markets, or that the observed male/female wage differentials are not due to labor market discrimination.

In contrast, Black (1995) has shown that in an equilibrium search model, where at least some employers have a distaste for hiring women, male/female wage differentials will exist even if the marginal employer has no distaste for hiring women. ${ }^{1}$ This is because the presence of discriminatory employers who will never hire minority workers, and who cannot be identified ex-ante, raises the cost of search for minority workers. All employers recognize this additional cost and offer minority workers lower wages. In addition, this higher search cost means that minority workers will have poorer matches with their employers than nonminority workers. Finally, Black shows that in his model

\footnotetext{
${ }^{1}$ Other recent examples of the effect of discrimination in a search model include Bowlus (1997), Sasaki (1999), Rosén (2003) and Flabbi (2006).
} 
labor market discrimination can persist—-there is no mechanism driving discriminatory employers out of the market.

Of course differential search behavior between men and women, and therefore differences in wages, can also arise if there are differences in the value of nonmarket time. We hypothesize that the primary source of the difference in the value of nonmarket time between men and women is women's comparative advantage in childbearing and childrearing. We further hypothesize that this difference should vary with age, initially rising as women reach prime childbearing and childrearing age, and then declining. This alternative model implies that wage differentials between men and women will vary with age and, assuming male and female workers face the same wage offer distribution, differences between men and women in the length of search should also vary with age.

In this paper we empirically examine differences in search behavior, job tenure and wages of men and women to distinguish between differences due to discrimination and differences due to time varying differences in the value of nonmarket time. ${ }^{2}$ The empirical framework are equations modeling the duration of search and job tenure allowing for differences by gender and age to capture observed heterogeneity across individuals, and a series of wage equations with a corresponding specification. The key parameters of interest are the coefficients of the gender variable and its interactions with age. We apply a differences in differences estimation approach to identify the parameters of interest using samples of workers who are displaced from their jobs due to their plant closing. Using these data we examine differences between men and women in the length of displacement, the length of their first job after displacement, and in their wages in their

\footnotetext{
${ }^{2}$ We should be clear that we do not formally test the opportunity cost model against the Black (1995) model. Instead, we use these models to guide our empirical specification and to provide structure when interpreting our results.
} 
first job after displacement. We also examine how the difference between men and women in these outcomes varies with age.

We focus on displaced workers because we believe that differential search behavior between male and female displaced workers will be less affected by factors outside the model, such as differential investment in human capital, than search behavior of new entrants to the market or individuals reentering the market after a prolonged absence. Our data on displaced workers come from the 1979 National Longitudinal Survey of Youths (NLSY) data, which is a panel data set consisting of a random sample of individuals who were 14-22 years old in 1979. These data are useful for our study because they identify worker displacement relatively soon after it occurs, they cover a long time period allowing us to follow workers for a number of periods after they are displaced, and they contain a rich set of covariates. The obvious limitation of these data is that the oldest workers are 45 in 2002 so we cannot observe the search behavior of older workers.

Using our data we find that women experience a significantly longer period of displacement than men. The difference in the length of displacement between men and women is largest for the youngest workers, age 24 years or younger, smaller for workers age 25 to 29 , and essentially zero for workers age 30 to 35 and 35 to 39 , a pattern that closely matches fertility patterns for women. ${ }^{3}$ Once we limit our estimation to women for whom the number of children in the house does not increase prior to their finding a new job we find no significant difference in the length of displacement between men and women at any age. We also find that there is no statistically significant difference

\footnotetext{
${ }^{3}$ Women 40 years old and older have significantly longer periods of displacement then men over of the same age.
} 
between men and women of all ages in the length of tenure on their post-displacement job. Finally, while we find that women do earn lower wages than men in their postdisplacement job, these differences are largest for the youngest women in our samplethose most likely to have left the labor market for a period to have a child. Further, once we limit our sample to workers whose spell of displacement is relatively short, and to women who find a job without experiencing an increase in the number of children in the household, the male/female wage gap falls for the youngest women in our sample. All these results are consistent with a model in which differences in search behavior and outcomes between men and women are due to differences in nonmarket opportunities rather than to discrimination, although we recognize they are also consistent with other models of discrimination such as models of statistical discrimination.

The paper is organized as follows. In the next section we review the relevant literature and discuss the relevant theories. In section III, we outline our model and the estimation approach. We describe our data in section IV. In section V we present our results. We summarize our results and present conclusions in section VI.

\section{Theoretical Models of Employer Discrimination and Search}

Black (1995) Model of Employer Discrimination and Search

Black (1995) develops a model of employer discrimination in an equilibrium search model. In his model there are two types of workers, A and B, who have identical marginal products and value of nonmarket time. Workers receive utility from working both from the wages they receive and from job satisfaction. There are also two types of employers, non-discriminatory employers and discriminatory employers who have a 
distaste for employing type B workers and therefore will never offer type B workers a job.

Black shows that his model produces the standard results from search theoryworkers form a reservation utility level that is a function of their utility from home production and their cost of search. Workers then sequentially search over jobs until the utility level from a job exceeds their reservation utility level. Black goes on to show that the presence of discriminatory employers lowers the reservation utility level of type B workers. This is because searching over the jobs with discriminatory employers is costly but offers no benefits since discriminatory employers will never employ a type B worker. This in turn implies that type B workers will accept a job with a lower utility level due to both lower wages and lower job satisfaction. Black also shows that the wages of type B workers will be lower even if the marginal employer has no taste for discrimination. Since all employers know that type B workers have a lower reservation utility level, they will use their market power (which exists in an equilibrium search model) to offer type B workers a lower wage. Black also shows that an increase in the number of discriminatory employers has an ambiguous effect on the length of search for type B workers relative to type A workers. This is because, while the higher fraction of prejudiced employers makes it harder for type B workers to find a nonprejudiced employer who is willing to employ them and therefore leads to more search, it also reduces the reservation level of utility for these workers which leads to less search. Therefore, the overall effect is ambiguous.

There are three implications from the Black model that are relevant for our analysis. First, in the Black model the effect of discrimination on the length of a 
displacement spell is ambiguous. Second, the Black model predicts that the presence of any discriminatory employer will lead to lower wages for all discriminated workers.

Finally, the Black model predicts that workers who experience discrimination will take jobs with a lower match quality. Our empirical counterpart to job quality will be tenure in the post-displacement job arguing that poorer match quality will lead to jobs of shorter duration.

More recent work by Rosén (2003) and Flabbi (2006) are examples of other models of discrimination embedded in a equilibrium search model. However, for our purposes, both models are quite similar to the Black model and neither contains important additional implications. ${ }^{4}$

An extension to the Black (1995) model is a model where the reservation wage, or the outside option, varies with age. One possible reason that men and women could have different nonmarket opportunities is that women have a comparative advantage in having and raising children. This hypothesis goes back to Becker (1981) and is based on empirical evidence showing that women specialize in child care and home production while men specialise in market work.

Since having and raising children primarily occurs at younger ages, the differences in search behaviour due to relatively higher reservation utility should primarily occur at the early stage of careers. In particular, we would expect that younger women will have longer spells of displacement but that, once women leave the prime child bearing ages, there will be no difference in the length of displacement between men and women. In addition, conditional on finding a job after displacement, we would not

\footnotetext{
${ }^{4}$ Sasaki (1999) presents an equilibrium search model with co-worker discrimination. Again, however, for our purposes this paper has no additional implications.
} 
expect there to be any difference between men and women in the quality of the job match, and therefore no difference in tenure on the post-displacement job. Finally we would expect since younger women are the ones more likely to leave the labor market for an extended spell, younger women should have lower wages than men once they do return to the labor market. For older women who remain in the market their wages should be similar to the wage of older men.

\section{Previous Empirical Literature on Male/Female Differences in Search and Wages}

Much of the early empirical work examining gender differences in search and wages has focused on displaced workers. These studies found that women tend to experience longer spells of displacement (Podgursky and Swaim, 1987) and greater wage-loss due to displacement (Madden, 1987; Podgursky and Swaim, 1987; and Crossley et al., 1994). Both Madden (1987) and Crossley et al. (1994) examine wage growth prior to displacement as well as wage change after displacement. Since both studies find that wage levels and growth prior to displacement are similar for men and women they conclude that differential accumulation of specific human capital cannot account for the differences in wage loss from displacement. Instead the differences appear to be due to differences in search behavior between men and women (See Crossley et al., 1994).

More recent empirical research continues to find that women experience longer spells of displacement (Farber, 1997; Abbring et al., 2002; Kletzer and Fairlie, 2003). 
However, unlike the earlier literature, the more recent studies find that men and women experience a similar loss in wages after displacement.

In related work Bowlus (1997) estimates an equilibrium search model with three states: employment, unemployment, and out of the labor force. She examines how differences between men and women in the probability of occupying one of these states affect the male/female wage gap. She finds that gender differences in labor market behavior accounts for 20-30 percent of the male/female wage differential, with the remaining difference attributable to productivity differentials which include the effects of labor market discrimination.

The finding in the previous literature that women experience longer spells of displacement is consistent with our alternative theory that women will experience longer spells of displacement due to more valuable non-market opportunities. In contrast, the Black (1995) model makes no prediction concerning how search length should differ between men and women. However, no study has examined life-cycle changes in the differential search behavior between men and women, nor have they looked at the role of fertility in accounting for these differences, which is what we focus on in this paper.

\section{The Data}

Our data on displaced workers come from the NLSY which cover the period 1979-2002. The NLSY is a panel data set on individuals who were between 14 and 22 years old in 1979 when the survey began. They were interviewed every year between 1979 and 1994 and every two years after 1994. 
Data from each interview contain information on up to five jobs that an individual has held since the last interview along with information that allows jobs to be linked across interviews. For every job we know the date an individual started the job, as well as the number of weeks they have worked at the job up to the date of the interview. For jobs that an individual is no longer working at there is information on why they left the job, the date they left the job, and the total number of weeks they worked at the job prior to leaving. In order to focus on the search behavior of individuals who have left school, we only consider workers who indicate they were not enrolled in school at anytime since the last interview. We then identify a worker as being displaced from a job when they indicate they are no longer working at a job because their plant closed, and when the data indicate they are not working for the same employer in the subsequent interview. Since the information on plant closing is not available prior to 1984 , we can only identify displacement starting with the 1984 interview. ${ }^{5}$ We identify displacement through the 2002 survey. ${ }^{6}$ To limit ourselves to workers with reasonably strong attachment to the labor market, we only consider workers who are displaced from a job where they usually worked 17 or more hours a week. Finally we drop workers who have hourly wages below $\$ 1.50$ in 1993 dollars, or who have missing values for usual hours worked per day. We identify a worker's post displacement job as the first job we find where the worker usually works more than 20 hours a week and has worked at the job for more than

\footnotetext{
${ }^{5}$ Prior to 1984 these individuals were classified as laid off.

${ }^{6}$ To reduce possible problems with recall bias between 1984 and 1994 we only keep workers who were interviewed in the year prior to displacement. After the 1994 survey the next round of the NLSY was conducted in 1996. Therefore, displacement in the 1996 survey could have occurred as much as two years prior to the interview, in contrast to earlier surveys when displacement would have occurred at most one year prior to the survey.
} 
nine weeks. ${ }^{7}$ We measure the length of displacement as the number of weeks between the date they stopped working at the displacement job and the date they started at their post-displacement job. ${ }^{8}$ We consider workers who never find a job as being censored. ${ }^{9}$

Our final data contains 1322 displacement events. Since the same person can experience multiple displacements over the period of our data, and appear in the data more than once, we adjust all of the standard errors in our subsequent analysis to reflect this clustering. Table 1 presents summary statistics for the main variables we use in the analysis. In these data age, weeks of tenure, years of schooling and wages at displacement are all measured in the interview year where displacement occurs. Because weeks of experience, marital status and location information could be affected by the timing of displacement relative to the timing of the interview, we measure these variables in the interview prior to displacement. We measure weeks of experience for workers by summing the variable measuring the number of weeks worked since the previous interview, over all interviews up to the current interview. ${ }^{10}$

Looking at Table 1 we see that 43 percent of our displacement events involve women. We also see that this is a fairly young sample since workers are only 31 years old at displacement, on average, and have slightly over eight years of labor market experience (452 weeks divided by 52) and have worked for the displacement firm for

\footnotetext{
7 Prior to 1988 the NLSY did not collect any wage, industry or occupation information on jobs where an individual worked fewer than 20 hours a week or had fewer than 10 weeks of tenure. In order to be consistent, we imposed this restriction in every year.

${ }^{8}$ Given the structure of the data, workers who have more than one job when they are displaced will have a negative length of displacement. We drop these workers from the analysis.

${ }^{9}$ Seven percent of our workers are censored. Also, while there is significant attrition from the sample, we do not consider a worker as being censored if they do not appear in a subsequent interview. This is because workers frequently reappear in the survey after missing one or more interviews.

10 This will measure actual weeks worked for workers who enter the labor market after 1978. For the handful of workers who start working prior to 1978 this variable will measure total experience in the market since 1978 .
} 
approximately three years ( 155 weeks divided by 52 ). Table 1 also shows that only seven percent of our workers never find a post-displacement job and are therefore considered as censored and that, for those who do find a job after displacement, the average length between jobs is about 48 weeks. Finally, we see for those who do get a job after displacement, the hourly wage in the post displacement job is 0.1 percent less, on average, than the hourly wage in the displacement job.

Comparing the numbers in columns 2 and 3 in Table 1 we see that men and women are about the same age at displacement, but that women have more years of education and are much more likely to be married. In addition, women tend to have fewer weeks of experience but about the same tenure at the displacement firm. Table 1 also shows that women are slightly more likely to be censored than men. Finally, we see that, conditional on finding a job, women have almost twice as many weeks between jobs as men but they experience a similar change in hourly wages between the displacement and post-displacement job.

Table 2 presents the percent of displacements in our sample by year. Given the performance of the U.S. economy over this period, it is not too surprising to see that displacements are more likely to occur earlier in the period. Comparing the distribution of displacements for men and women we see that both men and women are more likely to experience displacement earlier in the period, and that there is not any notable difference in the timing of displacement by sex.

Table 3 presents more detailed information on the length of displacement. The numbers in this table include both censored and uncensored spells. ${ }^{11}$ Table 3 shows that

\footnotetext{
${ }^{11}$ For censored spells we measure the length of displacement as the number of weeks between the date of displacement and December 31, 2002.
} 
about 20 percent of displaced workers get a new job within a week, but that men are five percentage points more likely than women to obtain a job this quickly. Table 3 also shows that approximately 10 percent of our sample does not obtain a new job within two years of being displaced and that women are about twice as likely as men to experience a gap of two years or longer between jobs.

We feel these data have a number of characteristics that make them ideal for studying differences in search behavior between men and women. First, they allow us to identify search that occurs after an exogenous job loss. By focusing on the differences in search behavior between men and women after an exogeneous job loss our results should be less sensitive to unobserved factors, such as differential investment in human capital, that could affect the search behavior of individuals who are initially entering the labor market or who are returning to the labor market after a prolonged absence. ${ }^{12}$ Our assumption is that unobserved differences will be captured in the characteristics of the previous job and that by focusing on changes we will control for these unobserved differences. Second, these data also contain a rich set of covariates that we can use to control for any remaining differences in search between men and women. Third, the frequency of these data should minimize the effect of recall bias that is present in other data sources on displaced workers. Fourth, the fact that we are focusing on a single cohort of workers means we should minimize any differential change in the labor force participation of men and women. Finally, the length of these data ensures that we are able to follow workers for an extended period after displacement and thereby minimize the effects of censoring.

\footnotetext{
${ }^{12}$ One possible concern with these data is that men and women have different attrition rates from the sample. However, data from the 2002 wave show that 65 percent of men and 68 percent of women remain in the sample - so it does not appear that attrition varies by sex.
} 
We should mention that recent research has called into question our assumption that job loss due to displacement is truly exogenous (Bowlus and Vilhuber, 2002 and Lengermann and Vilhuber, 2002). Two possibilities are that more able workers leave the plant prior to its closing or that plants containing the least able workers on average are more likely to close. However, since we are focusing on differences between men and women (essentially a difference-in-difference strategy) this possibly endogenous relationship between displacement and worker ability should not affect our results. ${ }^{13,14}$

While these data have a number of strengths, they also have some obvious weaknesses; the main one being the variation in age in these data. First, because these workers are between 14 and 22 years old in 1979, the range of age at displacement is limited, varying between 19 and 45 years old. Therefore, we have somewhat limited observations on workers beyond prime child bearing and child rearing ages. Second, because this is a cohort of workers of about the same age, the main source of variation in age is due to the timing of displacement—older displaced workers are those who are displaced later in the sample period. However, the fact that we are focusing on differences between men and women should again help mitigate this problem. To further control for possible year effects we will also include dummy variables for the year of displacement in all of our regressions.

\footnotetext{
${ }^{13}$ One change over this period that could affect the type of workers displaced is the passage of the Worker Adjustment and Retraining Notification (WARN) Act, which requires employers with 100 or more employees to notify workers 60 days prior to a layoff or plant closing that will affect 50 or more employees. However, WARN became effective in February 1989, which is fairly early in our sample. In addition, WARN should have a similar impact on men and women. For these reasons we do not believe that this change impacted our results.

${ }^{14}$ Another concern is that women and men react differently to plant closings, possibly due to different roles within the household. For example, men might be more likely to leave prior to a plant closing. However, our focus on workers with strong attachments to the labor market should help mitigate this possible problem.
} 


\section{Empirical Examination of Men's and Women's Search Behavior}

\section{Length of Displacement}

In this section we examine differences between men and women in the length of displacement. We start with Figure 1 which presents the estimated Kaplan-Meyer survival function for men and women. In this figure the estimated survival function for women lies completely above the survival function for men indicating that women experience longer spells between jobs — although a formal statistical test fails to reject the hypothesis that survival functions for men and women are equal. ${ }^{15}$ This is consistent with the results in Table 3; however the results presented in Figure 1 control for censoring. These results are also consistent with previous research showing that women experience longer spells of displacement than men (Podgursky and Swaim, 1987; Crossley et al., 1994; Farber, 1997; Abbring et al., 2002; Kletzer and Fairlie, 2003).

Figure 2 presents estimates of the survival function for men and women by age categories. Throughout this analysis we divide workers into five age categories: 24 years old or younger; 25-29 years old; 30-34 years old; 35-39 years old; and 40 years old or older. Table 1 shows the distribution of observation by these age categories. Figure 2 shows that there is an observable difference between men and women in the estimated survival function for workers that are 24 years old or younger, that the difference appears smaller for workers 25-29 years old, that the two functions appear virtually identical for 30-34 and 35-39 year olds, but that there is again a large difference in the functions for workers 40 years old or older. A test of the equality of the two functions in each figure

\footnotetext{
${ }^{15}$ We use the log-rank test to test for the equality of the two functions. The log-rank test compares the actual and expected number of failures in each group at a point in time.
} 
reject the hypothesis that the functions are equal for the younger than 24 , the $25-29$ and the 40 and over groups, but fails to reject the hypothesis for the two other age groups.

Next we present results from estimating a model where the dependent variable is the length of displacement. Because the dependent variable is a duration, a hazard model seems like the obvious choice since a hazard model allows us to deal with censoring in a fairly straight forward fashion. The main issue when estimating a hazard model is specifying the distribution of the baseline hazard function. We have chosen to avoid this issue by estimating a Cox proportional hazard model which does not require us to specify the exact parametric form of the underlying hazard function, but does require us to assume that changes in the hazard function are proportional. Given the estimates of the survival function presented in Figures 1 and 2, this appears to be a reasonable assumption. $^{16}$

The results from our regressions are presented in Table 4. In all of our models we control for age using the five age categories discussed previously. ${ }^{17}$ We also include a quadratic in experience and tenure, years of schooling completed, a race dummy (white vs. nonwhite), a set of year dummies indicating the year a worker was displaced and controls for the worker's industry at displacement (nine categories). In this table we present estimates of the hazard ratio which shows the proportional change in the hazard when the variable is increased by one unit. A ratio of less than one indicates the hazard

\footnotetext{
${ }^{16}$ We have also estimated parametric hazard models assuming the underlying hazard function has a: Weibull, log normal and generalized gamma distribution, and the results from all of these models are similar. These results are available from the authors upon request.

${ }^{17}$ We have estimated all of our models using continuous measures of age and age squared and the results are identical. We present the results using the age categories for illustrative purposes.
} 
declines as the variable increases while a hazard ratio of greater than one indicates a positive relationship between the hazard and the variable.

The results for our entire sample are presented in column (1). These results are fairly typical for the displaced worker literature (Carrington, 1990; Fallick, 1993; Fallick, 1996; and Abbring et al., 2002)). We see that the length of displacement increases with age and tenure while it decreases with labor market experience. Also more educated workers, married workers and nonwhite workers have shorter spells of displacement.

In columns (2) and (3) we present results from samples of just men and just women, respectively. Comparing the results in these two columns we see that men and women have a similar estimated relationship between most of the control variables and the length of the displacement spell. ${ }^{18}$ The one notable exception are the age variables. The hazard ratio estimates on the age categories show that for men the expected length of displacement is increasing with age. In contrast for women the positive relationship between age and spell length only occurs in the 35-39 and 40 and older categories. These results suggest that we can pool the data on men and women when estimating the hazard model as long as we include an interaction between sex and age.

To see exactly how the length of the displacement spell varies by sex and age the results in columns (4) and (5) come from models estimated on the entire sample including a complete interaction between a female dummy variable and the age categories. In column (5) we also include controls for a worker's occupation in the displacement job (nine categories). Focusing on the results in column (4) we see that women 24 years old or younger have a significantly longer expected spell length than men of similar age. The

\footnotetext{
${ }^{18}$ We have estimated the model on the pooled data including interactions between the female dummy variable and all of the other control variables. We fail to reject the hypothesis that the coefficients on the interaction between the female variable and all of the other variables, except the age variables, are zero.
} 
same is true for men and women 25-29, although the difference is smaller. Among workers age 30-35 and 35-39 there is no significant difference in the expected duration of nonemployment between men and women. Finally, among the oldest workers women again have a significantly longer displacement spell than men. We see the identical pattern in column (5) when we control for occupation. These results show that, while women have longer spells of displacement than men, this is due to differences in spell lengths among the youngest and oldest workers.

With the exception of the results for the oldest workers, the life-cycle patterns of relative spell length fit well with our model that differences in search behavior are due to differences in nonmarket opportunities related to child bearing and raising. Table 5 presents age specific fertility rates for U.S. women for years corresponding to the time period of our data. This table shows that fertility rates initially rise as women age, reach a peak among 25-29 year old women and then drop rather quickly after age 30 . The ages in which women have longer displacement spells corresponds to the ages in which fertility rates are high and rising and the ages in which men's and women's length of search are similar corresponds to ages in which women's fertility rates are low and falling.

We see a similar fertility pattern among women in our sample. Table 6 presents the number of children living in the household at displacement and the number of children living in the household at the start of the post-displacement job separately for women and men in our sample. For censored spells we have used the number of children reported living in the household in the 2002 survey. This table shows that among the youngest women in our sample there is a 50 percent increase in the number of children 
between the displacement and the post-displacement job. There is a 16 percent increase among women age $25-29$, but among women 30 years old or older there is only a very small increase or a decrease in the number of children living in the household. When we focus on women who experience displacement spells of 26 weeks or more the pattern is even more dramatic. Among the youngest age categories there is between a 38 to 113 percent increase in the number of children, while among women over 30 there is between a 2 percent increase and an 11 percent decline in the number of children living in the household. In contrast, for men we see that there is very little difference in the relationship between changes in the number of children in the household and the length of the displacement spell.

Finally column (6) in Table 4 presents results from our hazard model estimated on the entire sample of male workers but only including women who have either no change or a decline in the number of children living in the household between the time of displacement and the start of the displacement job. ${ }^{19,20}$ We see that among this sample there is no significant difference in the estimated hazard ratio for any age category. Taken together the results in Tables 4-6 suggest that any difference between men and women in the length of search after displacement is due to younger women who are displaced choosing to have children prior to returning to the labor market and does not appear to be directly related to discrimination in the labor market.

\section{Tenure on the Post-Displacement Job}

\footnotetext{
${ }^{19}$ To restate, for women who are censored we take the difference between the number of children in the household at displacement and the number of children in the household reported in the 2002 survey.

${ }^{20}$ Estimating the regression on a sample that also excludes men who live in households where the number of children increases between the displacement and post-displacement job produces nearly identical results.
} 
In this section we examine tenure on the post-displacement job. ${ }^{21}$ Recall that the Black (1995) model predicts that workers who experience discrimination will accept a job with lower match quality than workers who do not experience discrimination. Since a job with a lower quality match should end sooner, the Black model predicts that if women experience discrimination they should have a shorter tenure on their postdisplacement job. In contrast, if differences between men and women in search behavior are due to differences in nonmarket activity, in particular women's comparative advantage in having and raising children, then, conditional on a woman deciding to accept a job, we would not expect any difference in tenure on the post-displacement job.

We begin our analysis with Figure 3 which presents the estimated survival function for remaining in the post-displacement job. We see in this figure that the survival functions for men and women are virtually identical showing that men and women have similar tenure in the post-displacement job. Figure 4 presents the estimated survival function for remaining on the post-displacement job for men and women by our five age categories. In this figure we still see very little differences within the age categories in the estimated survival functions for men and women. For all of the functions in Figures 3 and 4 we never fail to reject the hypothesis that the survival functions for men and women are equal.

In Table 7 we present the results from estimating a proportional hazard model where the dependent variable is the length of the post-displacement job. We include the same set of controls in these regressions as we did in the previous regressions except we have dropped the tenure variables from the model and we measure marital status at the

\footnotetext{
${ }^{21}$ Throughout this analysis in this sub-section our sample consists of workers we observe obtaining a job after being displaced.
} 
start of the post-displacement job. ${ }^{22}$ In these results, since the dependent variable is tenure on the post-displacement job, a hazard ratio below one indicates a lower probability of failure and therefore a longer tenure on the post-displacement job. Looking at the results for the entire sample we see that more experienced workers and married workers remain at the post-displacement job for longer. The estimated effects on years of schooling and nonwhite are insignificant. Looking at the age effects we see that tenure on the post-displacement job is increasing with age, although only the estimates for the two oldest categories are significant at standard levels of significance.

Comparing the results in column (2) for men with the results in column (3) for women we see that the estimated effects are fairly similar. ${ }^{23}$ In particular, for both men and women, duration on the job is an increasing function of age.

In columns (4) and (5) we present results from our estimation where we include interactions between the female dummy variable and the age categories. In neither of these regressions do we find any significant difference between men and women in the estimated tenure on the post-displacement job. Further, it is only among the younger workers where the point estimate suggests that women have a shorter tenure than men, but these estimates are imprecisely estimated. The overall conclusion from the analyses in this section is that there does not appear to be any significant difference between men and women in the length of the post-displacement job suggesting that women are not accepting jobs with a lower match quality.

\footnotetext{
${ }^{22}$ We have estimated a version of the model including tenure and on the previous job and its square and these variables were insignificant so we dropped them from the final model.

${ }^{23}$ Estimating the model on the pooled data and including a complete interaction between the female dummy variable and all of the other control variables shows that the only interactions that are significantly different from zero are the female-experienced squared and female-marital status interactions.
} 


\section{Wages on Post-Displacement Job}

In this section we examine worker wages on the post-displacement job. ${ }^{24}$ Recall that the Black (1995) model suggests that the group experiencing discrimination will accept a job paying a lower wage, all else equal. Of course there are a number of other reasons why women's wages might be less than the wages of comparable men. In particular, the model of effort in the labor market developed in Becker (1981) suggests that women who engage in time intensive nonmarket activities, such as caring for children, will earn lower wages than men. This implies that, if there are wage differentials between men and women, they should be largest among the youngest women since these are the women most likely to be caring for children. In addition, since we have already seen that these younger women are the ones who experience the longest spell of displacement, any depreciation of human capital would also imply that young women will again be the ones who have the lowest wages relative to men.

We begin this analysis with Table 8 which presents the results from standard OLS wage regressions where the log of the hourly wage at the start of the post-displacement job is the dependent variable. ${ }^{25}$ In all of these regressions we have included the same

\footnotetext{
${ }^{24} \mathrm{We}$ are going to focus on workers who obtain a post-displacement job and ignore the possibility that workers who obtain a post-displacement job are a select sample. Recall, however, that we observe a postdisplacement job for 93 percent of our sample indicating that the effects of selection should be minimal.

${ }^{25}$ We have also estimated regressions where the dependent variable is the log of the change in worker wages between the displacement and the post-displacement job. We find no significant difference between men and women at any age in the change in wages as a result of being displaced. These results parallel the results seen in the recent empirical research on displaced workers (Farber, 1997; Abbring et al., 2002; Kletzer and Fairlie, 2003). Results are available from the authors upon request.
} 
controls that we included in our previous regressions. ${ }^{26}$ In column (1) we present results where we have included a female dummy variable. The coefficient on this variable indicates that female workers earn 16 percent lower wages on average than similar male workers.

In columns (2) and (3) we present results where we have interacted the female dummy variable with the age dummies. In column (3) we drop the controls for occupation and industry since there is some question whether these variables are exogeneous and should be included in the regression. Since the basic pattern of the results is similar in the two columns we will focus on the results in column (2).

The coefficient on the age-female interaction terms follows a pattern that is strikingly similar to the pattern seen in our hazard estimation of the length of displacement. The youngest workers in our sample have wages that are 16 percent less than the youngest males in the sample. This difference grows to 22 percent in the 25-29 age categories. The wage differential between men and women than falls dramatically in the 30-34 and 35-39 age categories and the difference is insignificant for both of these groups. Finally, the wage differential is largest among the oldest workers in the sample.

To examine the role that displacement length and fertility have on postdisplacement wages, column (4) contains results from a wage regression where we only include workers who obtain a job within 32 weeks of being displaced and only include women living in households where the number of children does not increase between the

\footnotetext{
${ }^{26}$ The one exception to this statement is we have dropped the controls for tenure of the previous job since it is not clear why tenure on the previous job should affect wages on the current job. In addition, when we included controls for tenure on the previous job the coefficients were insignificant.
} 
displacement and post-displacement job. ${ }^{27}$ Changing the sample in this way primarily affects the estimated male-female differential among the young workers in our sample. The estimated differential among the youngest workers falls from 15 percent to 6 percent and becomes statistically insignificant. Among 25-29 year old workers the differential falls from 22 to 20 percent. Among the older workers there is almost no change in the estimated wage differential. While there are still significant differences in wages between men and women, these results suggest that differential search behavior due to fertility decisions on the part of women accounts for at least some of the observed male/female wage differential.

\section{Conclusion}

Incorporating discriminatory employers in an equilibrium search model can produce differences in search behavior between men (the majority group) and women (the group experiencing discrimination) which leads to persistent differences in men's and women's wages. Previous empirical analysis suggests that there are differences in the search behavior of men and women that can account for some of the observed male/female wage gap. However, an alternative model in which there are differences in men's and women's nonmarket opportunity due to fertility could also produce differential search behavior, particularly during prime child bearing years. In this paper we have examined how search behavior varies between men and women over the life-cycle and whether fertility decisions can account for some of the observed differences in search.

\footnotetext{
${ }^{27}$ Estimating the regression on a sample that also excludes men who live in households where the number of children does not increase between the displacement and post-displacement jobs produces nearly identical results.
} 
Using data on displaced workers from the NLSY we find that women experience longer spells of displacement than men. However, we find that these differences are primarily the result of differences in search between men and women during prime childbearing years for women (29 years or younger). Once we restrict our sample to women who do not experience an increase in the number of children in the household prior to finding a post-displacement job there is no significant difference in the length of displacement between men and women. In addition, we find no evidence that women take jobs with a lower match quality at any age. Finally, we find that women's wages in the post-displacement job are lower than the wages for similar men. Again, however, this is primarily due to differences in wages among the youngest men and women in our sample. Once we focus on men and women who find a job within 32 weeks of being displaced and focus on women who live in households where the number of children does not increase during the displacement spell, we find smaller differences in wages between men and women. All of these findings are consistent with a model where fertility decisions on the part of women are driving the observed differences in search behavior. 


\section{References}

Abbring, Jaap; Gerard J. van den Berg, Pieter A. Gautier, A. Gijsbert C. van Lomwel, Jan C. van Ours, Christopher J. Ruhm, 2002). "Displaced Workers in the United States and the Netherlands," in: Losing work, moving on Peter J. Kuhn (ed.), pp.105-194.

Becker, Gary S., 1971. The Economics of Discrimination (Chicago, IL: The University of Chicago Press).

Becker, Gary S., 1981. A Treatise on the Family (Cambridge, MA: Harvard University Press).

Black, Dan A., 1995. "Discrimination in an Equilibrium Search Model." Journal of Labor Economics, Vol. 13, (April): 309-334.

Bowlus, Audra J., 1997. "A Search Interpretation of Male-Female Wage Differentials," Journal of Labor Economics, Vol. 15 (October): 625-657.

Bowlus, Audra and Lars Vilhuber, 2002. "Displaced workers, early leavers, and reemployment wages." mimeo, November.

Carrington, William J. 1990. “Specific Human Capital and Worker Displacement.” Diss., University of Chicago.

Crossley, Thomas F., Stephen R.G. Jones, Peter Kuhn, 1994. "Gender Differences in Displacement Cost: Evidence and Implications," Journal of Human Resources, 29(2): 461-480.

Farber, Henry S. 1997. "The Changing Face of Job Loss in the United States, 19811995.” Brookings Papers on Economic Activity: Microeconomics, pp. 55-142.

Fallick, Bruce C., 1993. “The Industrial Mobility of Displaced Workers.” Journal of Labor Economics, Vol. 11 (April): 302-323.

Fallick, Bruce C., 1996. "A Review of the Recent Empirical Literature on Displaced Workers.” Industrial and Labor Relations Review, Vol. 50 (October): 5-16.

Flabbi, Luca, 2006. "Gender Discrimination Estimation in a Search Model with Matching and Bargaining." mimeo, October.

Kletzer, Lori and Robert W. Fairlie, 2003. "The Long-Term Costs of Job Displacement for Young Adult Workers.” Industrial and Labor Relations Review Vol. 56 (July): 682-698. 
Lengermann, Paul and Lars Vilhuber, 2002. Abandoning the Sinking Ship: The Composition of Worker Flows Prior to Displacement." mimeo, September.

Madden, J., 1987. "Gender differences in the cost of displacement: An empirical test of discrimination in the labor market," American Economic Review, 77(2): 246-51.

Podgursky, M. and P. Swaim, 1987. "Job displacement and earnings loss: Evidence from displaced worker survey," Industrial and Labor Relations Review, 41(1): 17-29.

Rosén, Ása, 2003. “Search, Bargaining, and Employer Discrimination.” Journal of Labor Economics Vol 21 (October): 807-829.

Sasaki, Masaru, 1999. "An Equilibrium Search Model with Coworker Discrimination." Journal of Labor Economics, Vol. 17 (April): 377-407. 
Table 1: Summary Statistics for the Sample of Displaced Workers

\begin{tabular}{lccc}
\hline \hline & Entire Sample & Men & Women \\
& $(1)$ & $(2)$ & $(3)$ \\
\cline { 2 - 4 } & 1.00 & 0.57 & 0.43 \\
Proportion less than 24 years old & 0.16 & 0.17 & 0.15 \\
Proportion 25 to 29 years old & 0.30 & 0.29 & 0.30 \\
Proportion 30 to 34 years old & 0.21 & 0.22 & 0.20 \\
Proportion 35 to 39 years old & 0.21 & 0.20 & 0.23 \\
Proportion 40 or older & 0.11 & 0.11 & 0.12 \\
Weeks of full time experience prior to displacement & 451.66 & 470.13 & 427.20 \\
Weeks of tenure in job displaced from & 154.97 & 155.07 & 154.84 \\
Highest grade completed at displacement in years & 12.20 & 12.15 & 12.27 \\
Proportion post displacement job observed & 0.93 & 0.95 & 0.91 \\
Length of displacement in weeks* & 47.85 & 38.94 & 59.65 \\
Proportion full time job prior to displacement & 0.87 & 0.92 & 0.80 \\
Proportion full time job in first post displacement job* & 0.75 & 0.84 & 0.62 \\
Tenure in post displacement job in weeks & 140.40 & 138.78 & 142.62 \\
Proportion change industry & 0.60 & 0.60 & 0.59 \\
Proportion change occupation & 0.57 & 0.58 & 0.56 \\
Hourly wage on displacement job & 9.26 & 10.16 & 8.07 \\
Change in log hourly wage & -0.01 & -0.01 & -0.01 \\
Log hourly wage displacement job & 2.07 & 2.17 & 1.94 \\
Hourly wage post displacement job & 9.21 & 10.17 & 7.92 \\
Proportion married & 0.62 & 0.57 & 0.68 \\
Number of displacement observations & 1322 & 753 & 569 \\
\hline \hline
\end{tabular}

Note: *These means only include non-censored observations. 
Table 2: Distribution of Displacement by Year

\begin{tabular}{cccc}
\hline \hline Year & $\begin{array}{c}\text { Entire Sample } \\
(1)\end{array}$ & $\begin{array}{c}\text { Men } \\
(2)\end{array}$ & $\begin{array}{c}\text { Women } \\
(3)\end{array}$ \\
\hline 1983 & 5.14 & 5.44 & 4.75 \\
1984 & 7.11 & 6.51 & 7.91 \\
1985 & 7.49 & 7.04 & 8.08 \\
1986 & 7.19 & 7.17 & 7.21 \\
1987 & 5.98 & 6.64 & 5.10 \\
1988 & 5.30 & 5.05 & 5.62 \\
1989 & 6.66 & 6.64 & 6.68 \\
1990 & 5.14 & 4.78 & 5.62 \\
1991 & 4.46 & 4.38 & 4.57 \\
1992 & 4.01 & 4.12 & 3.87 \\
1993 & 2.57 & 3.59 & 1.23 \\
1994 & 3.78 & 4.38 & 2.99 \\
1995 & 4.39 & 4.78 & 3.87 \\
1996 & 4.46 & 3.85 & 5.27 \\
1997 & 5.30 & 5.31 & 5.27 \\
1998 & 4.92 & 5.31 & 4.39 \\
1999 & 3.71 & 3.59 & 3.87 \\
2000 & 4.77 & 4.25 & 5.45 \\
2001 & 5.14 & 5.18 & 5.10 \\
2002 & 2.50 & 1.99 & 3.16 \\
\hline \hline
\end{tabular}


Table 3: Distribution of Displacement by Length of Displacement

\begin{tabular}{lccc}
\hline \hline & Entire Sample & Men & Women \\
& $(1)$ & $(2)$ & $(3)$ \\
\cline { 2 - 4 } Up to 1 week & 20.50 & 22.71 & 17.57 \\
2-20 weeks & 40.24 & 41.83 & 38.14 \\
21-32 weeks & 10.29 & 9.96 & 10.72 \\
33-52 weeks & 9.08 & 8.90 & 9.31 \\
53-104 weeks & 10.21 & 9.69 & 10.90 \\
More than 104 weeks & 9.68 & 6.91 & 13.36 \\
\hline \hline
\end{tabular}


Table 4: Proportional Hazard Estimation of the Length of Displacement

\begin{tabular}{|c|c|c|c|c|c|c|}
\hline & $\begin{array}{c}\text { Entire Sample } \\
\text { (1) }\end{array}$ & $\begin{array}{l}\text { Men } \\
(2)\end{array}$ & $\begin{array}{l}\text { Women } \\
\text { (3) }\end{array}$ & $\begin{array}{c}\text { Entire Sample } \\
\text { (4) }\end{array}$ & $\begin{array}{c}\text { Entire Sample } \\
\text { (5) }\end{array}$ & $\begin{array}{c}\text { Limited Sample } \\
\text { (6) }\end{array}$ \\
\hline \multirow[t]{2}{*}{ Age $25-29$} & 0.89 & 0.87 & 0.96 & 0.88 & 0.87 & 0.87 \\
\hline & $(-1.14)$ & $(-1.02)$ & $(-0.24)$ & $(-1.05)$ & $(-1.07)$ & $(-1.08)$ \\
\hline \multirow[t]{2}{*}{ Age $30-34$} & 0.75 & 0.59 & 1.04 & 0.63 & 0.63 & 0.61 \\
\hline & $(-1.97)$ & $(-2.55)$ & $(0.18)$ & $(-2.78)$ & $(-2.66)$ & $(-2.82)$ \\
\hline \multirow[t]{2}{*}{ Age $35-59$} & 0.59 & 0.47 & 0.72 & 0.50 & 0.51 & 0.49 \\
\hline & $(-2.64)$ & $(-2.70)$ & $(-1.10)$ & $(-3.17)$ & $(-3.06)$ & $(-3.13)$ \\
\hline \multirow[t]{2}{*}{ Age $40+$} & 0.54 & 0.62 & 0.47 & 0.62 & 0.65 & 0.67 \\
\hline & $(-2.60)$ & $(-1.42)$ & $(-2.20)$ & $(-1.80)$ & $(-1.59)$ & $(-1.48)$ \\
\hline \multicolumn{7}{|l|}{ Female $\mathrm{x}$} \\
\hline Age $20-24$ & - & - & - & 0.67 & 0.68 & 0.99 \\
\hline & & & & $(-2.82)$ & $(-2.58)$ & $(-0.07)$ \\
\hline Age $25-29$ & - & - & - & 0.72 & 0.74 & 1.02 \\
\hline & & & & $(-3.14)$ & $(-2.62)$ & $(0.21)$ \\
\hline Age $30-34$ & - & - & - & 1.02 & 1.05 & 1.18 \\
\hline & & & & $(0.20)$ & $(0.39)$ & $(1.35)$ \\
\hline Age 35-39 & - & - & - & 1.02 & 1.04 & 1.18 \\
\hline & & & & $(0.11)$ & $(0.25)$ & $(1.18)$ \\
\hline Age $40-45$ & - & - & - & 0.53 & 0.52 & 0.54 \\
\hline & & & & $(-3.01)$ & $(-3.16)$ & $(-2.90)$ \\
\hline \multirow[t]{2}{*}{ Experience } & 1.002 & 1.003 & 1.003 & 1.002 & 1.002 & 1.003 \\
\hline & $(4.44)$ & $(3.34)$ & $(3.22)$ & $(4.46)$ & $(4.43)$ & $(4.64)$ \\
\hline \multirow[t]{2}{*}{ Experience Squared } & 1.000 & 1.000 & 1.000 & 1.000 & 1.000 & 1.000 \\
\hline & $(-2.38)$ & $(-1.78)$ & $(-1.97)$ & $(-2.48)$ & $(-2.50)$ & $(-2.65)$ \\
\hline \multirow[t]{2}{*}{ Tenure } & 0.9984 & 0.9988 & 0.9973 & 0.9984 & 0.9984 & 0.998 \\
\hline & $(-3.4)$ & $(-2.01)$ & $(-3.25)$ & $(-3.45)$ & $(-3.46)$ & $(-3.32)$ \\
\hline \multirow[t]{2}{*}{ Tenure Squared $(* 1000)$} & 1.000002 & 1.000002 & 1.000002 & 1.000002 & 1.000002 & 1.000002 \\
\hline & $(2.69)$ & $(2.26)$ & $(2.05)$ & $(2.80)$ & $(2.79)$ & $(2.65)$ \\
\hline \multirow[t]{2}{*}{ Nonwhite } & 1.05 & 1.10 & 0.94 & 1.03 & 1.04 & 1.03 \\
\hline & $(0.82)$ & $(1.30)$ & $(-0.68)$ & $(0.52)$ & $(0.65)$ & $(0.55)$ \\
\hline \multirow[t]{2}{*}{ Years of schooling completed } & 1.06 & 1.06 & 1.05 & 1.06 & 1.05 & 1.06 \\
\hline & $(3.37)$ & $(3.23)$ & $(1.84)$ & $(3.55)$ & $(3.05)$ & $(3.26)$ \\
\hline \multirow[t]{2}{*}{ Married } & 1.07 & 1.12 & 1.04 & 1.10 & 1.10 & 1.14 \\
\hline & $(1.04)$ & $(1.33)$ & $(0.42)$ & $(1.59)$ & $(1.56)$ & $(2.08)$ \\
\hline Year dummies & Yes & Yes & Yes & Yes & Yes & Yes \\
\hline Industry dummies & Yes & Yes & Yes & Yes & Yes & Yes \\
\hline Occupation dummies & No & No & No & No & Yes & Yes \\
\hline Number of Observations & 1322 & 753 & 569 & 1322 & 1321 & 1247 \\
\hline Log Likelihood & -7735.06 & -4056.17 & -2820.93 & -7721.55 & -7710.66 & -7267.52 \\
\hline
\end{tabular}

Note: The table shows the hazard ratio along with z-scores in parenthesis. All standard errors have been corrected for clustering. All variables are measured at the time of displacement. The limited sample in column (6) includes all men but only includes women who are living in households where the number of children did not increase between displacement and the post-displacement job. 
Table 5: Age Specific Fertility Rates for Selected Years

(Live births per 1,000 women)

\begin{tabular}{lcccccc}
\hline \hline & $\begin{array}{c}15-19 \\
(1)\end{array}$ & $\begin{array}{c}20-24 \\
(2)\end{array}$ & $\begin{array}{c}25-29 \\
(3)\end{array}$ & $\begin{array}{c}30-34 \\
(4)\end{array}$ & $\begin{array}{c}35-39 \\
(5)\end{array}$ & $\begin{array}{c}40-44 \\
(6)\end{array}$ \\
\cline { 2 - 6 } 1980 & 53.0 & 115.1 & 112.9 & 61.9 & 19.8 & 3.9 \\
1985 & 51.0 & 108.3 & 111.0 & 69.1 & 24.0 & 4.0 \\
1990 & 59.9 & 116.5 & 120.2 & 80.8 & 31.7 & 5.5 \\
1995 & 56.0 & 107.5 & 108.8 & 81.1 & 34.0 & 6.6 \\
2000 & 47.7 & 109.7 & 113.5 & 91.2 & 39.7 & 8.0 \\
\hline \hline
\end{tabular}

Source: Nation Center for Health Statistics, http://www.cdc.gov/nchs/data/statab/t001x07.pdf 
Table 6: Number of Children Living in the Household with Displaced Workers

\begin{tabular}{|c|c|c|c|c|c|c|}
\hline \multirow[b]{2}{*}{ Age } & \multicolumn{3}{|c|}{ Entire Sample } & \multicolumn{3}{|c|}{ Displacement Spell 26 weeks or Longer } \\
\hline & $\begin{array}{c}\text { Number of Children } \\
\text { at Displacement }\end{array}$ & $\begin{array}{l}\text { Number of Children } \\
\text { at Post-Displacement } \\
\text { Job }\end{array}$ & $\begin{array}{c}\text { Proportional } \\
\text { Change }\end{array}$ & $\begin{array}{c}\text { Number of Children } \\
\text { at Displacement }\end{array}$ & $\begin{array}{c}\text { Number of Children } \\
\text { at Post-Displacement } \\
\text { Job }\end{array}$ & $\begin{array}{c}\text { Proportional } \\
\text { Change }\end{array}$ \\
\hline \multicolumn{7}{|c|}{ Panel A--Women } \\
\hline 24 years old or younger & 0.58 & 0.87 & 0.50 & 0.55 & 1.17 & 1.13 \\
\hline 25-29 years old & 0.98 & 1.14 & 0.16 & 1.03 & 1.42 & 0.38 \\
\hline 30-34 years old & 1.62 & 1.68 & 0.04 & 1.79 & 1.83 & 0.02 \\
\hline 35-39 years old & 1.80 & 1.70 & -0.06 & 1.79 & 1.70 & -0.05 \\
\hline 40 years old or older & 1.50 & 1.34 & -0.11 & 1.30 & 1.16 & -0.11 \\
\hline \multicolumn{7}{|c|}{ Panel B--Men } \\
\hline 24 years old or younger & 0.28 & 0.41 & 0.46 & 0.30 & 0.35 & 0.17 \\
\hline 25-29 years old & 0.68 & 0.79 & 0.16 & 0.61 & 0.54 & -0.11 \\
\hline 30-34 years old & 0.88 & 0.88 & 0.00 & 0.88 & 0.88 & 0.00 \\
\hline 35-39 years old & 1.26 & 1.27 & 0.01 & 1.42 & 1.38 & -0.03 \\
\hline 40 years old or older & 1.18 & 1.14 & -0.03 & 1.20 & 1.23 & 0.03 \\
\hline
\end{tabular}


Table 7: Proportional Hazard Estimation of the Length of Post Displacement Job

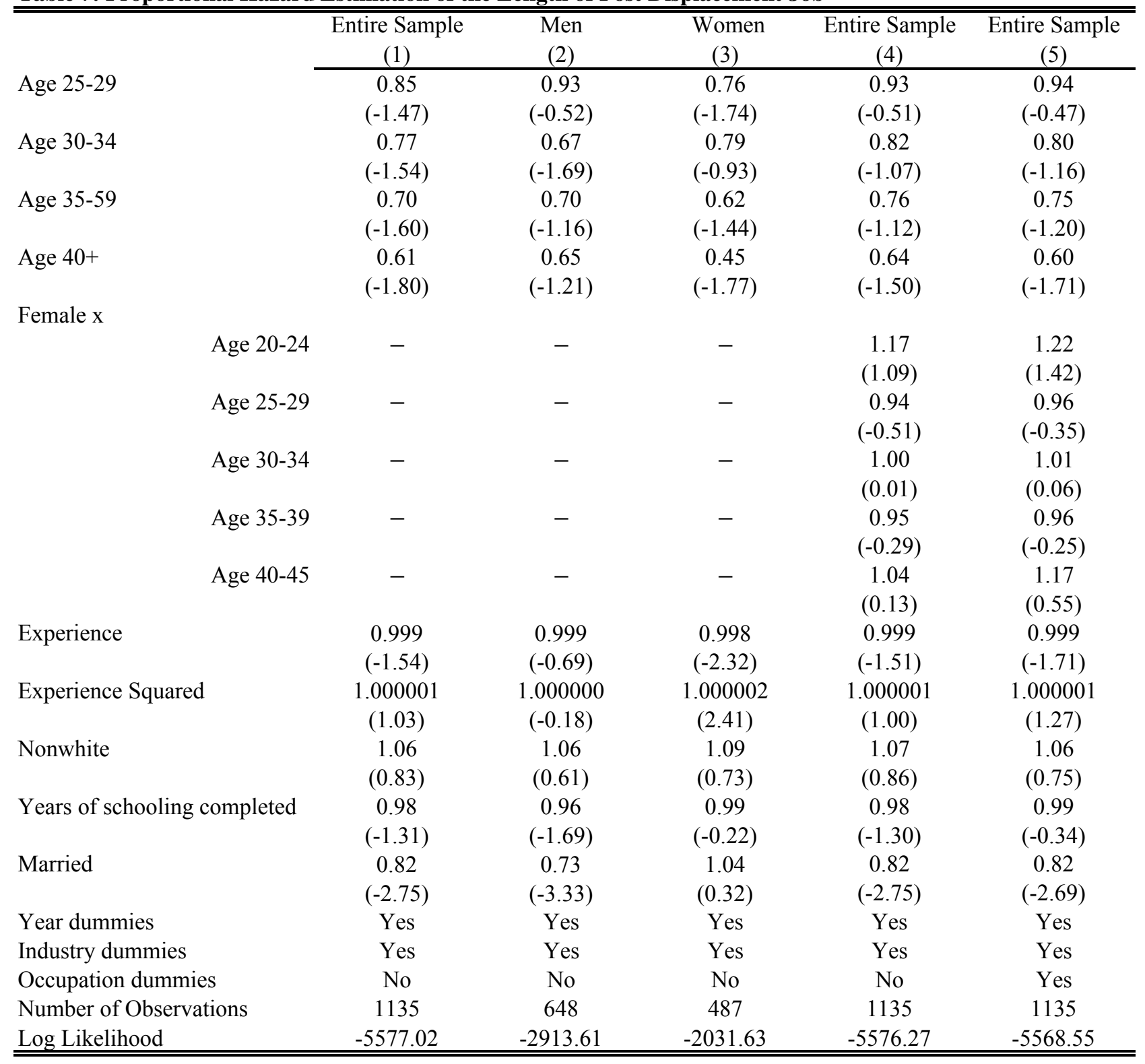

Note: The table shows the hazard ratio along with z-scores in parenthesis. All standard errors have been corrected for clustering. 
Table 8: Regression of the Log Hourly Wage in the Post-Displacement Job

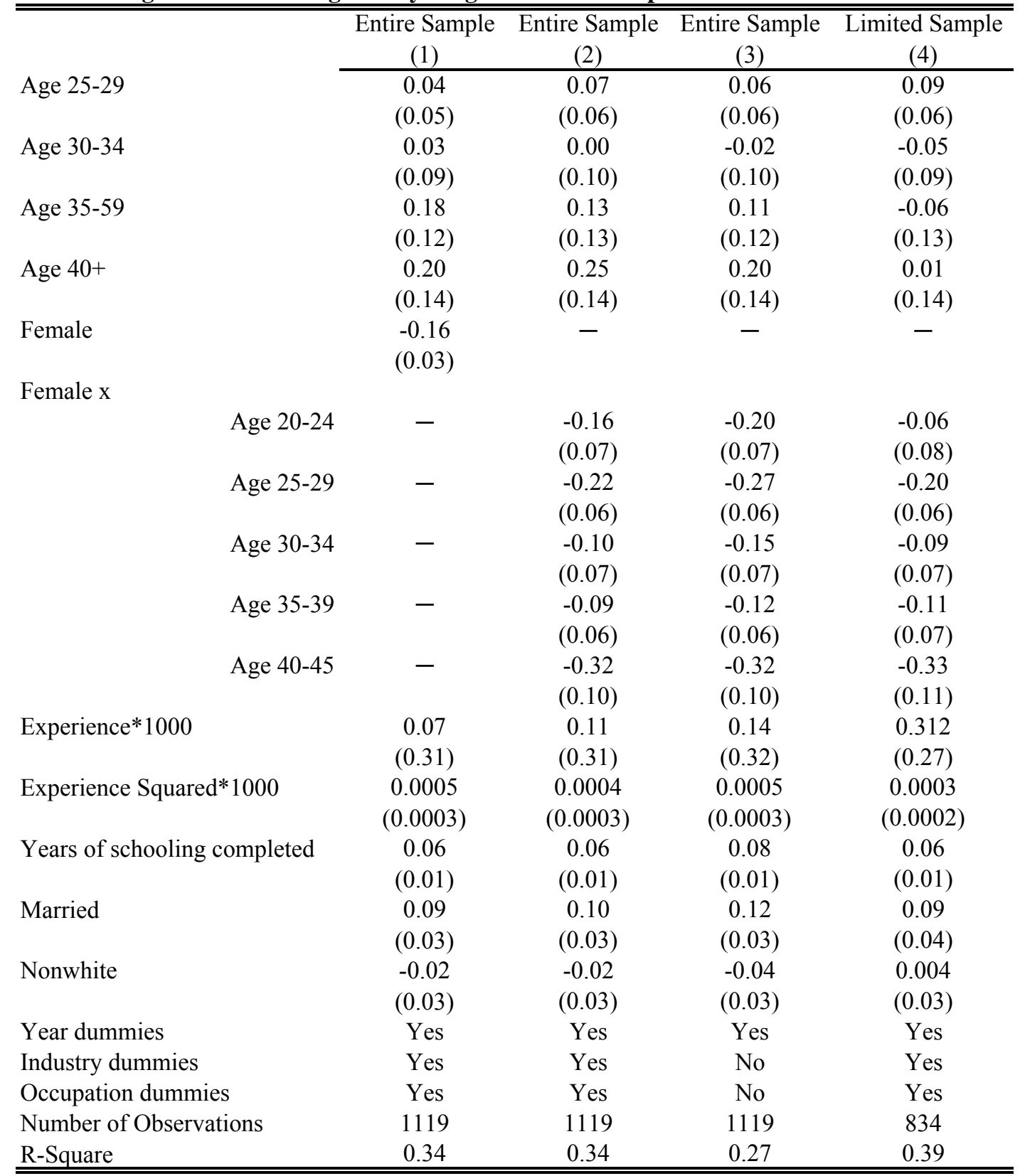

Note: The table shows the OLS regression coefficient along with standard error in parenthesis. All standard errors have been corrected for clustering. All variables are measured at the time of displacement. The limited sample in column (4) only includes workers who find a job within 32 weeks of being displaced and only includes women living in households where the number of children did not increase between displacement and the post-displacement job. 


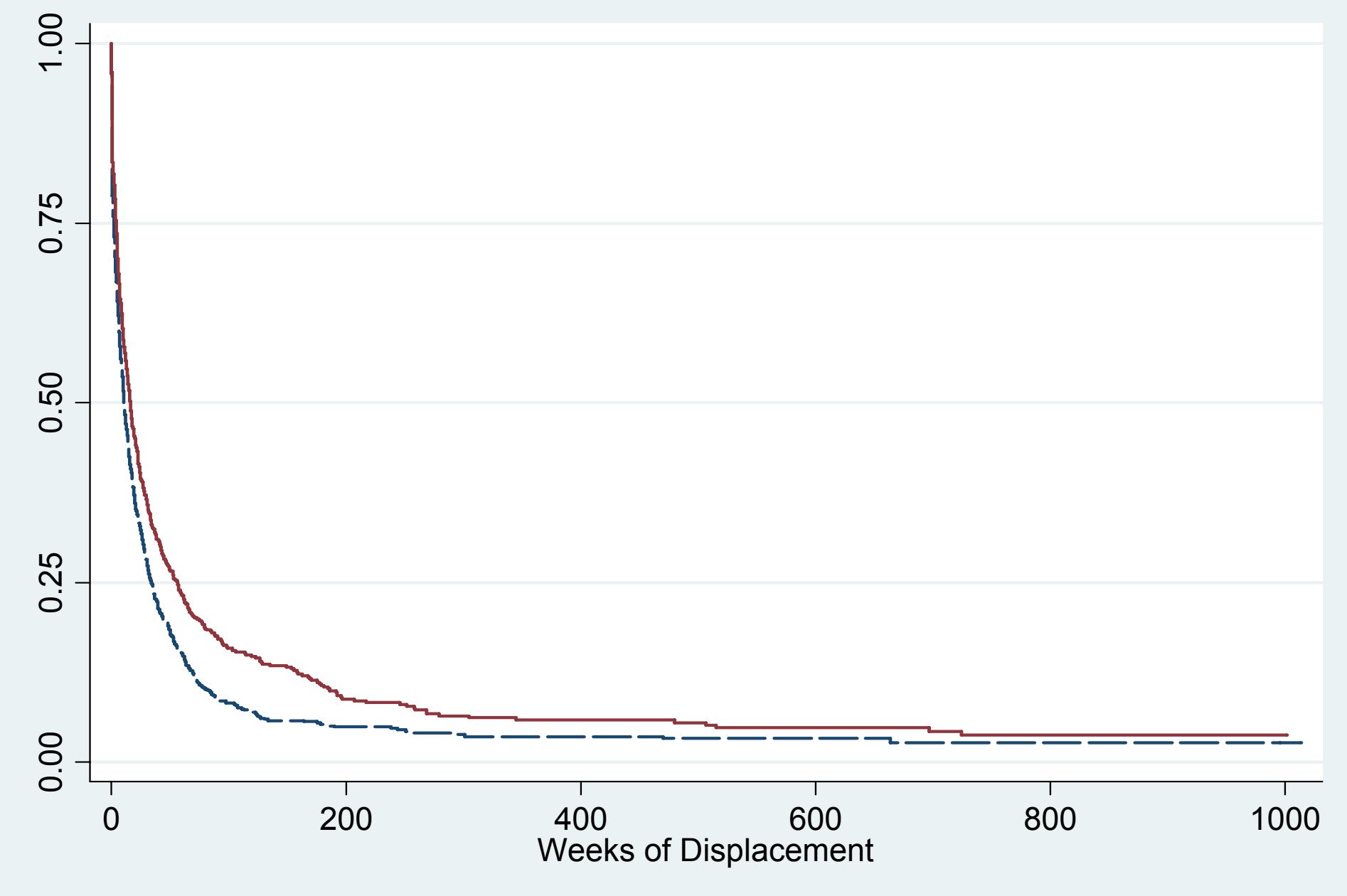

Male

Female

Figure 1: Survival Function of Length of Displacement by Gender 


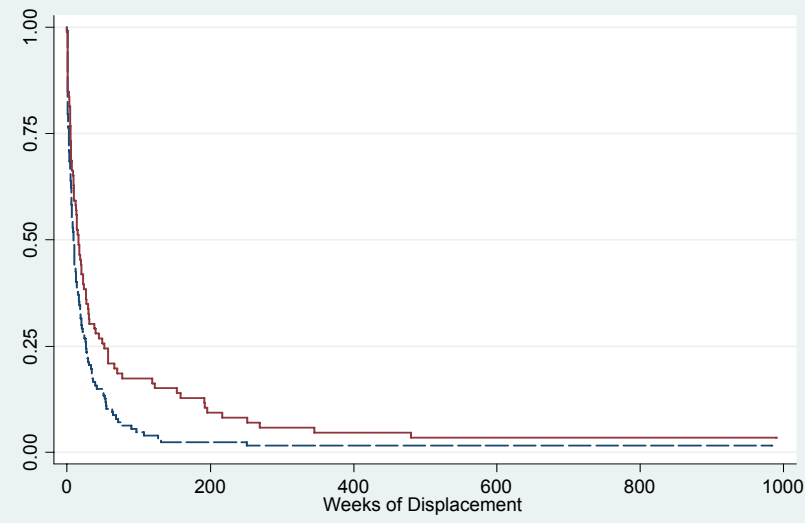

Panel A: Under 24 years old

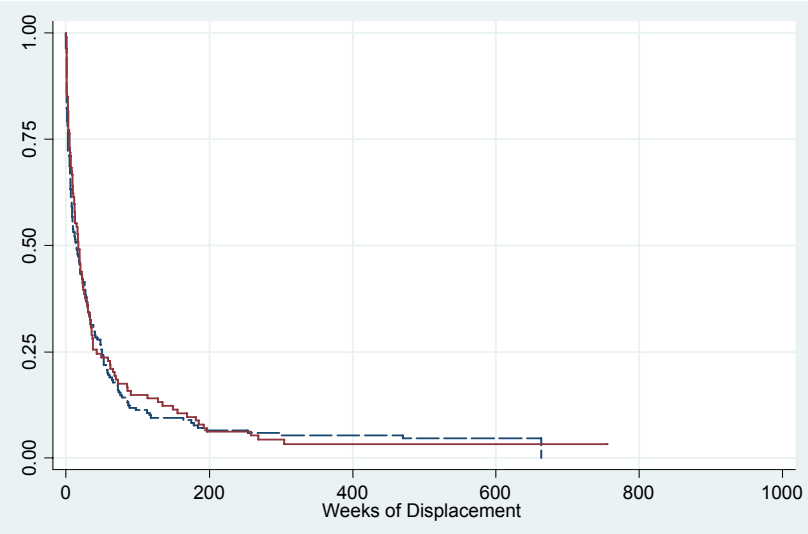

Panel C: Between 30 to 34 years old

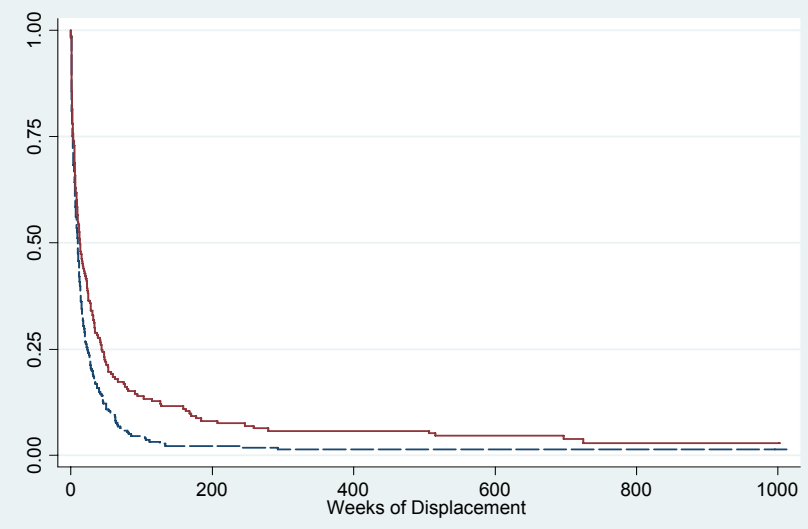

Panel B: Between 25 to 29 yrs olds

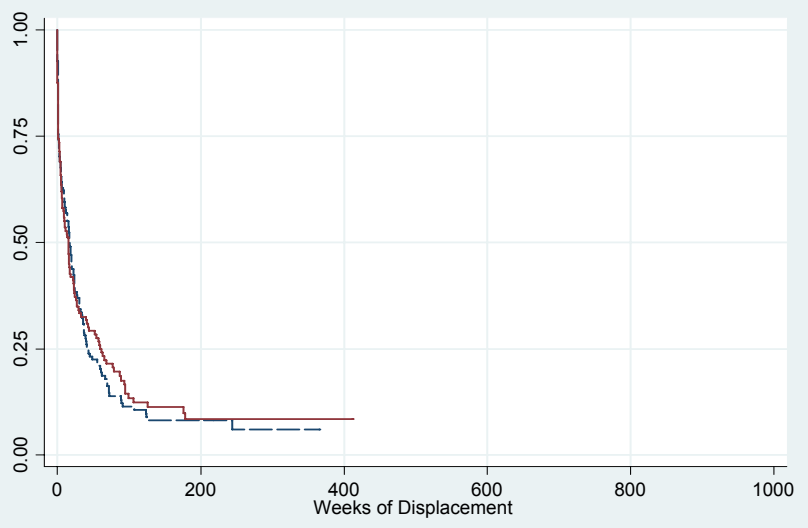

Panel D: Between 35 to 39 years old

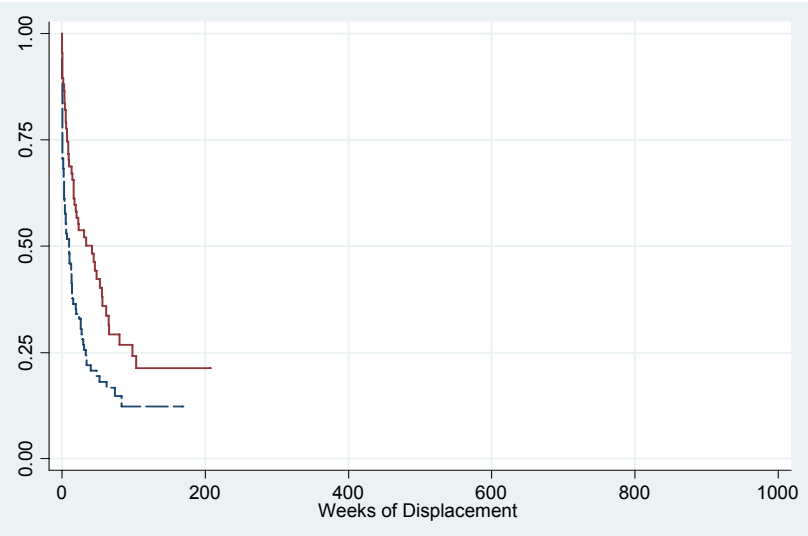

Panel E: 40 years old and older

Figure 2: Survival Function of Length of Displacement by Age and Gender 


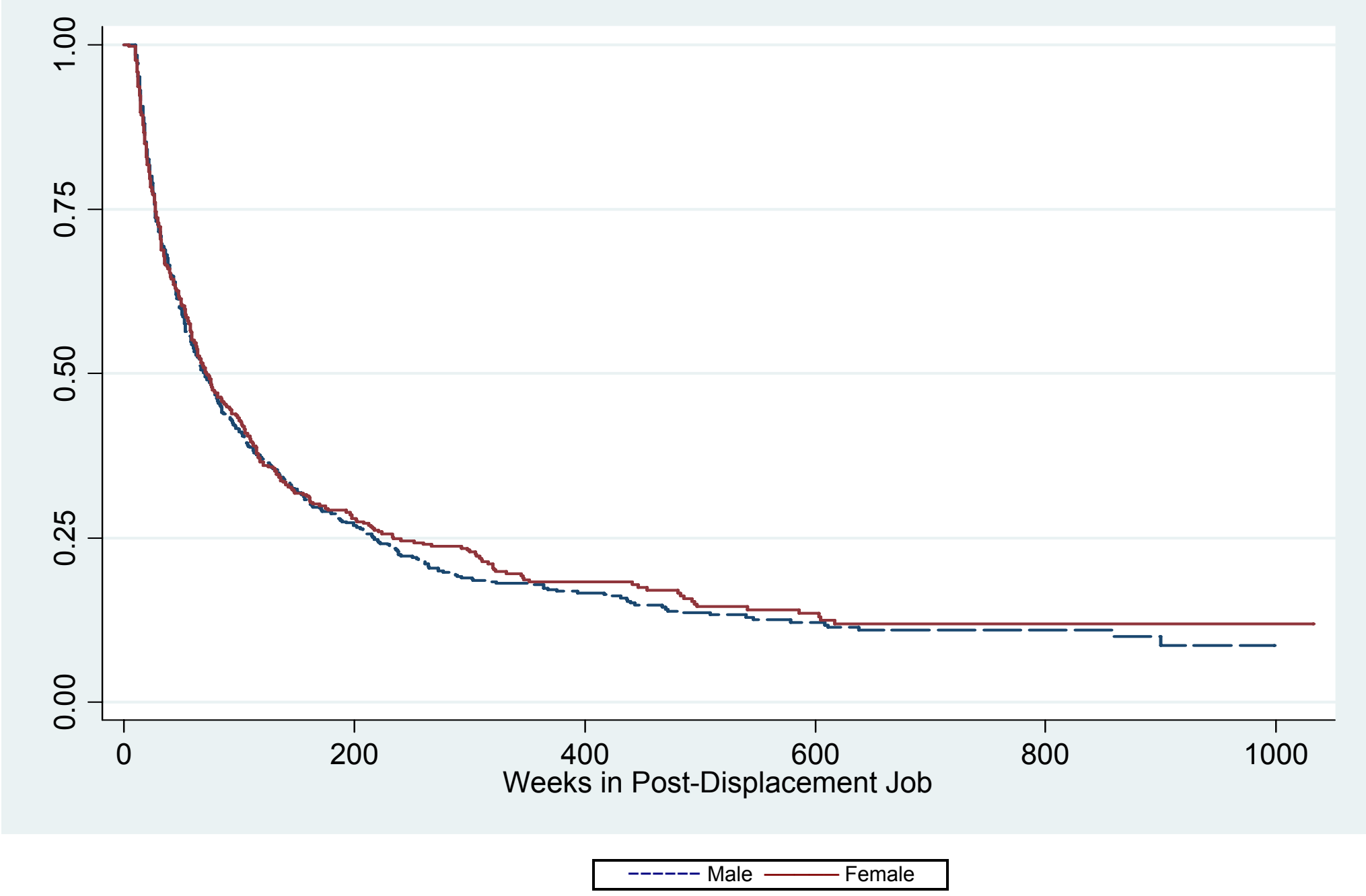

Figure 3: Survival Function of Length of Post-Displacement Job by Gender 


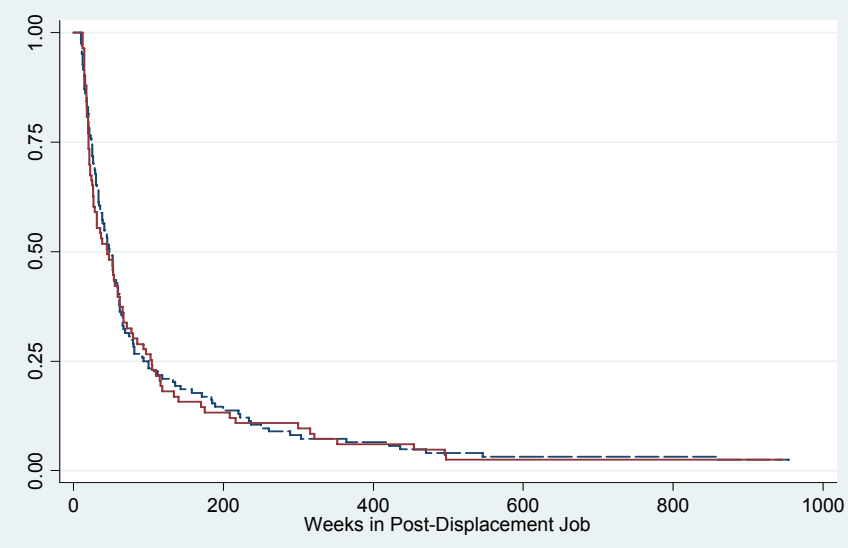

Panel A:Under 24 years old

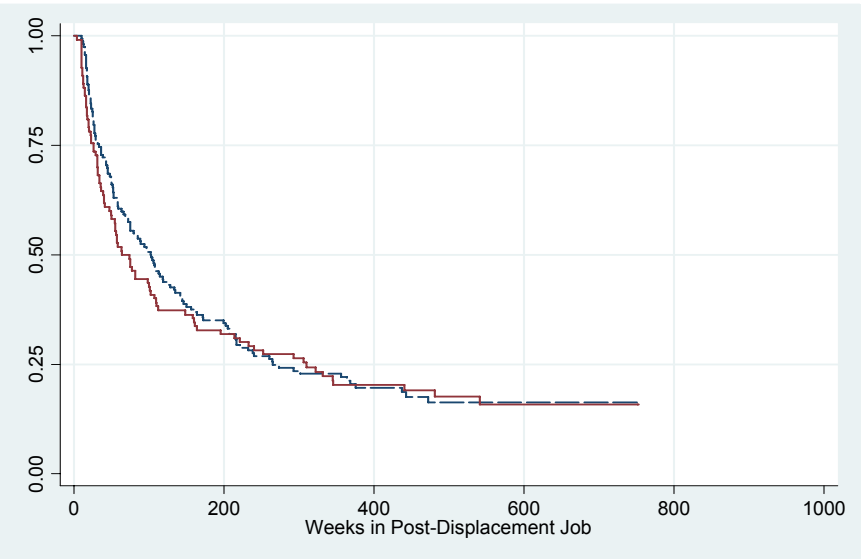

Panel C: Between 30 to 34 years old

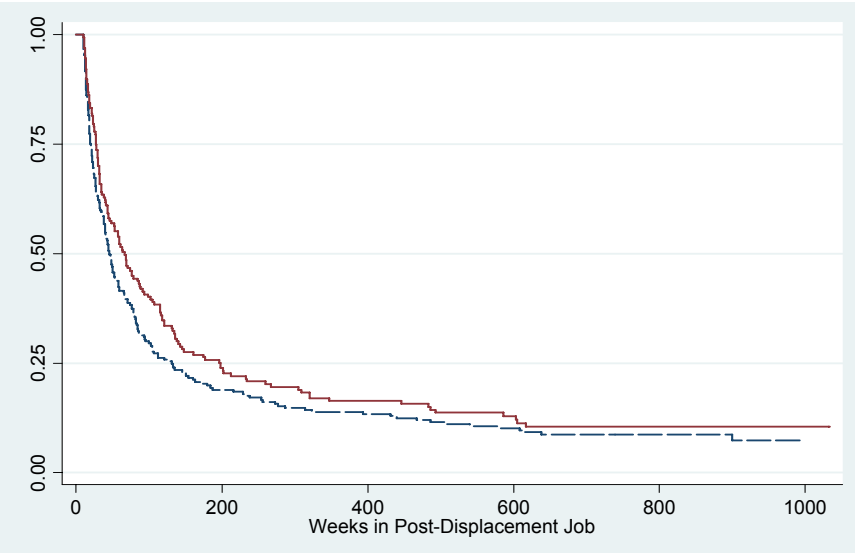

Panel B: Between 25 to 29 years old

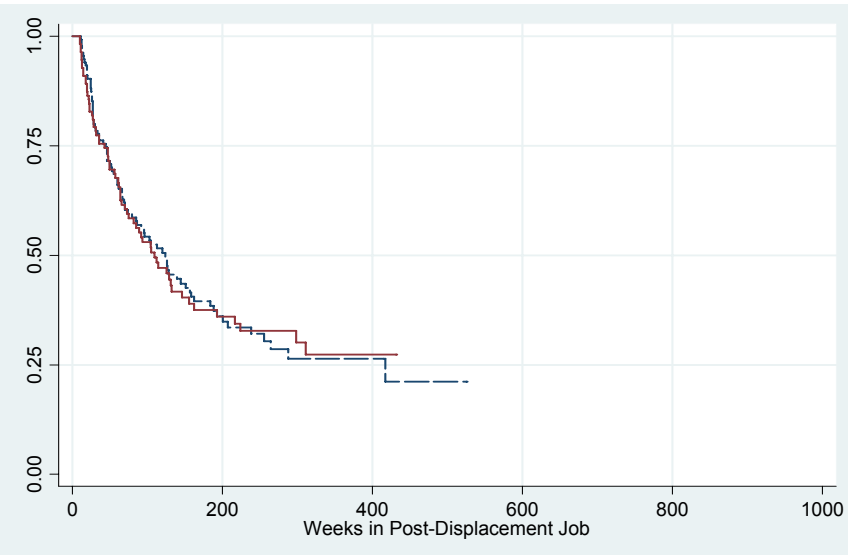

Panel D: Between 35 to 39 years old

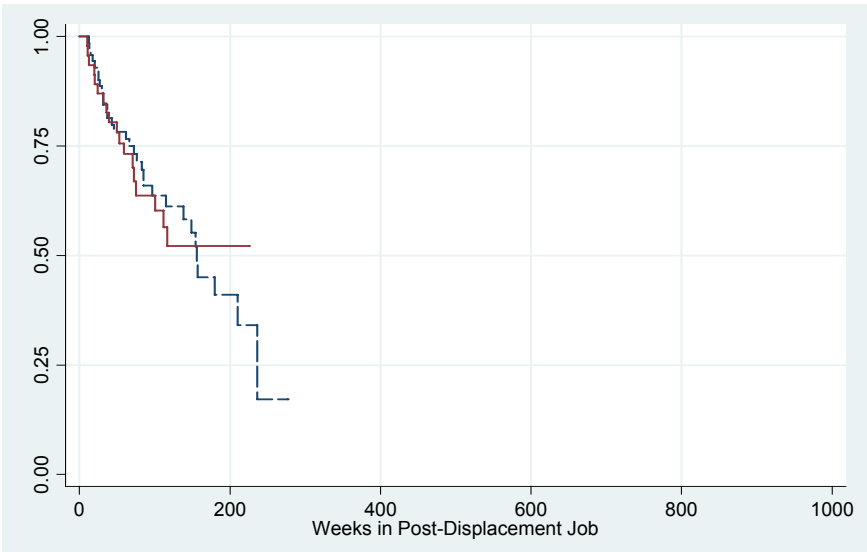

Panel E: 40 years old and older

------ Male $\longrightarrow$ Female

Figure 4: Survival Function of Length of Post-Displacement Job by Age and Gender 